Production Practices and Quality Assessment of Food Crops Volume 4 


\section{Production Practices and Quality Assessment of Food Crops}

Volume 4

Proharvest Treatment and Technology

Edited by

Ramdane Dris

World Food Ltd.

Helsinki, Finland

and

Shri Mohan Jain

FAO/IAEA Joint Division

International Atomic Energy Agency

Vienna, Austria 
eBook ISBN: $\quad 1-4020-2535-1$

Print ISBN: $\quad 1-4020-1701-4$

C2004 Springer Science + Business Media, Inc.

Print C2004 Kluwer Academic Publishers

Dordrecht

All rights reserved

No part of this eBook may be reproduced or transmitted in any form or by any means, electronic, mechanical, recording, or otherwise, without written consent from the Publisher

Created in the United States of America

Visit Springer's eBookstore at:

http://www.ebooks.kluweronline.com and the Springer Global Website Online at:

http://www.springeronline.com 


\section{CONTENTS}

Preface

vii-viii

List of Authors

Application of Sensitive Trace Gas Detectors in Post-Harvest Research

S. T. Persijn, J. Oomens, Qingxu Yu, F. J. M. Harren, Rofandi Hartanto and Suparmo and M. A. J. Wasono

Radio Frequency Post-Harvest Quarantine and Phytosanitary Treatments to Control Insect Pest in Fruits and Nuts

Shaojin Wang and Juming Tang

Calcium, Polyamine and Gibberellin Treatments to Improve Postharvest Fruit Quality

María Serrano, Domingo Martínez-Romero, Mirna Zuzunaga, Fernando Riquelme and Daniel Valero

Ionization of Fruits and Vegetables for Fresh Consumption - Effect on Detoxificant Enzymatic Systems and the Lipid Fraction

J. R. Martinez-Solano, P. Sanchez-Bel, E. Olmos, E. Hellin, F. Romojaro and M. C. Martinez-Madrid

Treatments and Techniques to Minimise the Postharvest Losses of Perishable Food Crops

Elhadi M. Yahia, Catherine Barry-Ryan and Ramdane Dris

$95-133$

Strategies for the Regulation of Postharvest Fruit Softening by Changing

Cell Wall Enzyme Activity

Gabriel O. Sozzi

Postharvest Treatment of Fruits

Etelka Kovács

Postharvest Treatments of Satsuma Mandarin (Citrus Unshiu Marc.) for the Improvement of Storage Life and Quality

Tomislav Jemriić and Nikola Pavičić

Sprouting Radioinhibition: A Method to Extend the Storage of Edible Garlic Bulbs

G. A. Orioli, C. A. Croci and C. N. Pellegrini 
Post-Harvest Processing of Fruits and Vegetables by Ionizing Radiation Arun Sharma

Desinfestation of Fresh Horticultural Commodities by Using Hot Forced Air With Controlled Atmospheres

Lisa G. Neven 


\section{PREFACE}

We can not talk about commodity production without building up all the operations after harvest. It is possible to market the products just after harvest, but it is only possible in small quantities. Postharvest handling is the ultimate stage in the process of producing quality fresh fruits and vegetables, getting these unique packages of water (fresh commodities) to the supper table. Fresh fruits and vegetables are succeptible to a number of postharvest disease and disorders and the postharvest operations are predominately aimed at maintaining harvest quality. Every step in the handling chain can influence the extent of disease and quality of the stored product. From planting to consumption, there are many opportunities for bacteria, viruses, and parasites to contaminate produce or nutrient deficiency level causing physiological disorders. Most of the storage rots are diseases that have originated in the field and have carried over onto commodities after harvest. Physiological disorders also arise from poor handling between harvest, storage and marketing. Treatments have a direct effect on inactivating or outright killing germinating spores, thus minimising rots. Prestorage treatment appears to be a promising method of postharvest control of decay. Pre-or-postharvest treatments of commodities are considered as potentiel alternatives for reducing the incidence of diseases, disorders, desinfestation of quarantine pests and for preserving food quality. Postharvest treatments lead to an alteration of gene expression and fruit ripening can sometimes be either delayed or disrupted. the tolerance to high and low postharvest temperatures may be influenced by preharvest high temperatures of the crop. Cell wall degrading enzymes and ethylene production are frequently the most disrupted and are sometimes not produced or their appearance is delayed following heating.

Eleven chapters are included in this book, which are: Application of Sensitive Trace Gas Detectors in Post-harvest Research; Radio Frequency Post-Harvest Quarantine and Phytosanitary Treatments to Control Insect Pest in Fruits and Nuts; Calcium, Polyamine and Gibberellin Treatments to Improve Postharvest Fruit Quality; Ionization of Fruits and Vegetables for Fresh Consumption - Effect on detoxication Enzymatic Systems and the Lipid Fraction; Treatments and Techniques to Minimise The Postharvest Losses of Perishable Food Crops; Strategies for the Regulation of Postharvest Fruit Softening by Changing Cell Wall Enzyme Activity; Posthavest Treatment of Fruits; Postharvest Treatments of Satsuma mandarin (Citrus unshiu Marc.) For the Improvement of Storage Life and Quality; Sprouting Radioinhibition: A Method to Extend the storage of Edible Garlic Bulbs; Postharvest Processing of Fruits and vegetables by Ionizing Radiation; Desinfestation of Fresh Horticultural commodities by Using Hot Forced Air With Controlled Atmospheres.

This book covers various aspects of postharvest handling quality and the use of different treatments to reduce the incidence of diseases or physiological disorders affecting the quality maintenance of the food crops. Also described is the production, packaging, cooling, transportation, and marketing costs of crops. It is obvious that marketing positions are uncertain without a complex postharvest 
network. The challenge facing industries is to produce food of good quality with few chemical inputs as public concern increases over food safety, environmental issues and chemical resistance.

The editors wish to express their sincere gratitude to all authors for their valuable contributions. We are grateful to Kluwer Academic Publishers for giving us an opportunity to compile this book.

Ramdane Dris Ph.D.

World Food Ltd.

Meri-Rastilantie $3 C$

FIN-00980 Helsinki Finland

E-mail:info@world-food.net

info@world-food.net
Shri Mohan Jain Ph.D.

Plant Breeding and Genetics Section Joint FAO/IAEA Division

International Atomic Energy Agency

Wagramer Strasse 5

P.O. Box 200

A-1400 Vienna, Austria

E-mail:S.M.Jain@iaca.org 


\section{LIST OF AUTHORS}

F. J. M. Harren, Life Science Trace Gas Exchange Facility, Department of Molecular and Laser Physics, University of Nijmegen, the Netherlands.

S. T. Persijn ${ }^{\mathrm{a}}$, J. Oomens ${ }^{\mathrm{b}}$ and Qingxu Yu ${ }^{\mathrm{c}}$, Life Science Trace Gas Exchange Facility, Department of Molecular and Laser Physics, University of Nijmegen, the Netherlands; ${ }^{\text {a }}$ Current address: Soegijapranata Catholic University, Faculty of Agricultural Technology, Department of Food Technology, Semarang, Indonesia; ${ }^{\mathrm{b}}$ Permanent address: Institute of applied physics, Dalian University of Technology, Dalian, China; ${ }^{\mathrm{c}}$ Current address: FOM-Institute for Plasma Physics, Nieuwegein, The Netherlands.

Rofandi Hartanto Suparmo, Fakultas Teknologi Pertanian, Universitas Gajah Mada, Bulaksumur, Yogyakarta, Indonesia.

M. A. J. Wasono, Jurusan Fisika, FMIPA, Universitas Gajah Mada, Sekip Utara Bulaksumur, Yogyakarta, Indonesia.

Shaojin Wang and Juming Tang, Department of Biological Systems Engineering, Washington State University, 213 L.J. Smith Hall, Pullman WA 99164-6120, USA.

María Serrano, Domingo Martínez-Romero, Mirna Zuzunaga, Fernando Riquelme and Daniel Valero, Miguel Hernandez University, Ctra. Beniel, Km 3.2, 03312 Orihuela, Alicante, Spain, CEBAS-CSIC, Campus de Espinardo, 30100 Murcia, Spain.

Juan Ramón Martínez-Solano, Paloma Sánchez-Bel, Enrique Olmos, Eladio Hellín and Félix Romojaro, Centro de Edafologia y Biologia Aplicada del Segura, CSIC, Campus de Espinardo, Murcia, SPAIN, Apt. 4195, Spain.

Maria Concepción Martinez-Madrid, Escuela Politécnica Superior, Universidad Miguel Hernandez. Ctra. Beniel km 3.2, Orihuela, Alicante, Spain.

Elhadi M. Yahia, Faculty of Chemistry, Autonomous University of Queretaro, Queretaro, Qro., 76190, Mexico.

Catherine Barry-Ryan, School of Food Science \& Environmental Health, Dublin Institute of Technology, Cathal Brugha Street, Dublin 1, Ireland.

Ramdane Dris, World Food Ltd. Meri-Rastilantie 3 C, 00980 Helsinki. Finland.

Gabriel O. Sozzi, Cátedra de Fruticultura, Departamento de Producción Vegetal, Facultad de Agronomía, Universidad de Buenos Aires. Avda. San Martín 4453, C1417 DSE - Buenos Aires, Argentina.

Etelka Kovács, KEKI, Central Food Research Institute, H-1022 Budapest II, Herman Ottó út 15. Hungary.

Tomislav Jemrić and Nikola Pavićić, University of Zagreb, Faculty of Agriculture, Department of Pomology, Svetošimunska 25, 10000 Zagreb, Croatia.

G. A. Orioli, Bahia C. A. Croci and C. N. Pellegrini, Agronomy Department, Universidad National Del Sur, Altos del Palihue, 8000 Blanka, Argentina.

Arun Sharma, Food Technology Division, Bhabha Atomic Research Centre, Mumbai-400085, India.

Lisa G. Neven, Research Entomologist, USDA-ARS Yakima Agricultural Research Laboratory, 5230 Konnowac Pass Road, Wapato, WA 98951, USA. 